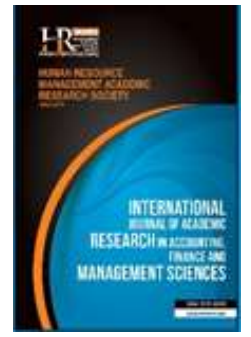

International Journal of Academic Research in Accounting, Finance and Management Sciences

Vol. 10, No.1, January 2020, pp. 1-12

E-ISSN: 2225-8329, P-ISSN: 2308-0337

(c) 2020 HRMARS

www.hrmars.com

To cite this article: Al kaabi, O.M.S.M., Adaikalam, J., Mahbub Karim, A.M. (2020). A Case Study on Budgetary Control Application in the Ministry of Interior, UAE, International Journal of Academic Research in Accounting, Finance and Management Sciences 10 (1): 1-12

\title{
A Case Study on Budgetary Control Application in the Ministry of Interior, UAE
}

\author{
Omar Mohammed Saeed Musabeh Al kaabi ${ }^{1}$, \\ Joseph Adaikalam², Asif Mahbub Karim ${ }^{3}$ \\ ${ }^{1}$ PhD Research Fellow, Binary University of Management \& Entrepreneurship, Malaysia \\ ${ }^{2}$ Founder and Executive Chairman, Binary University of Management \& Entrepreneurship, Malaysia \\ ${ }^{3}$ Dean \& Associate Professor, Binary Graduate School, Binary University of Management \& Entrepreneurship, Malaysia, \\ ${ }^{3}$ E-mail: drasifmkarim@gmail.com (Corresponding author)
}

Abstract

Oil prices have been on a roller-coaster ride over the last few years. This thesis examines the evaluation of budgetary control due to fluctuation of petroleum price. During the past 5 years, production of crude petroleum had been increasing steadily in the UAE. In 2014, ADNOC produced crude petroleum from onshore fields, including the Murban field, and from offshore fields, including the Lower Zakum, the Umm Shaif, and the Upper Zakum fields. The country used enhanced oil recovery (EOR) technologies to extract crude petroleum and natural gas from many of its oil-producing wells. The specific research objectives conducted in this study are to investigate effects on budget during petroleum price fluctuation and other objectives are, to examine impact of fiscal policy of UAE on the budget of UAE, to investigate effects of petroleum production on the budget of UAE and to investigate effects of OPEC regulation on petroleum production. The study was conducted in the ministry of interior, United Arab Emirates to undermine the evaluation of the budgetary control due to the fluctuation of petroleum price. Since the main source of revenue for the Government is petroleum so, the public sector budgets heavily depends on the global petroleum price and the fluctuation of it has a direct impact on the public sector operation. Ministry of interior being the key public sector is also within the strategic concern of the government revenue and its implication on its budgetary affairs. Based on the findings of the study the main recommendations made for the study are firstly, it is very common phenomenon for the oil price to fluctuate, hence alternative source of income to be generated so that dependency only from oil price for budget for the ministry of interior can be minimized. Secondly, to introduce new elements in the fiscal policy of the country as alternate source of government revenue likes looking into public revenue and expenses. Concentration on invisible exports to be considered. Like tourism, education, health care etc. Thirdly, reform of OPEC policy's on petroleum production per day quota need to be relooked due to persistent fall of the oil price as to adjust the supply and demand. The contribution from the researcher there is not cost elimination but there is an in built process now for cost minimization. Secondly, impact of the fiscal policy has a direct impact on the budget. As fiscal policy consist of taxation and government expenditure, so the government now should look for alternate indirect tax to increase the inflow for the government as a measure to reduce the negative burden on petroleum price fluctuations.

Key words

Budgetary Control, Oil Price, UAE

Received: 30 Jan 2020 (c) The Authors 2020

Revised: 10 Feb 2020 Published by Human Resource Management Academic Research Society (www.hrmars.com)

Accepted: $\quad 21$ Feb 2020 This article is published under the Creative Commons Attribution (CC BY 4.0) license. Anyone may 21 reproduce, distribute, translate and create derivative works of this article (for both commercial and Published Online: 09 Mar 2020 non-commercial purposes), subject to full attribution to the original publication and authors. The full terms of this license may be seen at: http://creativecommons.org/licences/by/4.0/legalcode 


\section{Introduction}

The oil prices were fluctuating more than ever in the two decades. Oil prices rose from 2004 to historic highs in mid-2008, only to fall precipitously in the last four months of 2008 and lose all the gains of the preceding four and a half years. The steep price increase from January 2007 to July 2008 was challenging for all economies. The barrel price drop in 2008 mainly due to the decreased oil demand in the United State. The oil price drop in the 2014 is not more than the 2008 price drop; however, the barrel price went below $\$ 40$ the lowest price since November 2001 where the barrel price was $\$ 25$.

According to Demirbas et al. (2017), the oil price volatility depends on the combined effects of invariant and variable factors. Invariant factors include feedstock prices, exploration costs, drilling costs, chemical composition of oil, production costs, distribution costs, marketing costs, and packaging and storage costs, while the variable factors include global economic activity, level of production, level of consumption, exchange value of the US dollar (\$), current supply and demand, geopolitical reasons, weather-related developments, and political events. Supply factors have played a more important role than demand factors in driving the 50\% drop in the oil price between mid-2014 and early 2015. The high uncertainty on both oil production and oil demand makes difficult the assessment of future oil price.

Oil prices rely on the forces of supply and demand and rising prices are often attributed to undersupply or an increase in demand. Other factors that may cause oil prices to increase include larger economic growth and market speculation over possible shortages in oil supply and delivery (Federal Reserve Bank of San Francisco, 2007). In the period from 2000 to 2007, the average Brent crude oil price in dollars per barrel went up quickly from $\$ 28.66$ in 2000 to $\$ 96.94$ by late 2007 to early 2008 (U.S. Energy Information Administration, 2014). The rise of oil prices during this period can possibly be credited to the economic expansion of large populous countries such as India and China, and an increasing concern over a possible shortage in the supply of oil given the political unrest in the Middle East, such as the Iraq War, which also resulted in an increasing demand for oil.

In 1972 oil price was \$3.5/barrel, but after the Arab-Israeli war in October 1973 and the oil embargo that followed oil price reached $\$ 12 /$ barrel at the end of 1974. In the period from 1974 to 1978 crude oil price fluctuated between $\$ 12.5$ and $\$ 14.5$ per barrel. Iranian-Iraqi War began in September 1980 and it decreased production of both countries with 6.5 million barrels/day representing less than $10 \%$ of world production, which led to an increase in the price of an oil barrel from \$14 in 1979 to $\$ 35$ in 1981 (Al Dulaimi, 2014). Fluctuations in the prices of physical supplies of crude oil affect the plans of processing enterprises and the cost of oil products. Changes in the prices of the wholesale and retail markets are a signal for traders and consumers making decisions about the purchase, storage or use of oil. This in turn affects the decision of processors on the volume of purchased oil. General changes in demand for crude oil are reflected in changes in demand for reference oil brands on stock exchanges. These data of the physical market are transferred to traders, who in turn offer futures contracts at the best price. Thus a closed circle of relationships is formed. A budget (derived from old French word meaning purse) is a quantified financial plan for a forthcoming accounting period (O'Sullivan et al., 2007).

Budget is an estimation of revenue and expenses over a specified future period of time; it is compiled and re-evaluated on a periodic basis. The budget of a government is a summary or plan of the intended revenues and expenditures of that government. There are three types of government budget: (1) the operating or current budget, (2) the capital or investment budget, and (3) the cash or cash flow budget.

\section{Literature review}

\subsection{Petroleum price fluctuation}

Since the petroleum become the major energy source there has been no other source which can provide that petroleum does to the world. Nations had started wars for the sake of petroleum, example: Second Gulf war. Like other commodity the petroleum price always been fluctuating. The oil prices have been fluctuating more than ever in the two decades. From the graph the barrel price drop in 2008 mainly due to the decreased oil demand in the United State. The oil price drop in the 2014 is not more than the 2008 price drop; however, the barrel price went below $\$ 40$ the lowest price since November 2001 where the barrel price was $\$ 25$. The high uncertainty on both oil production and oil demand makes difficult the assessment of future oil price. Futures markets can be useful to predict oil prices in the short-term, but 
they are not necessarily good at predicting in the long-term (Baumeister \& Kilian, 2015). According to Tim Bowler a business reporter at BBC, there are few reasons for the oil price drop significantly in 2014 . These reasons are given below:

- Slow growth of the growing countries like china and India in the last couple of years. Large number of population present in china and India.

- Increase oil exporting in some countries like Canada and Iraq which flood the market with oil.

Oil production in the United States increased significantly in last several years and this demand for importing oil decreases. According to EIA database, US field production of crude oil increased by $67 \%$ from 2011 to 2015, making the US the largest producer in the world surpassing Saudi Arabia and Russia.

United States currently use fraction technology and this technology help to extract oil from shale formation cheaper than ever.

- The appreciation of the US dollar which made crude oil more expensive for the rest of the world.

These fluctuations in price not only affect many countries and company but even normal people in many countries. Example: one of the biggest losers in the oil price drop in Russia , since about $70 \%$ of the country's export incomes comes from oil exportation according to 'Winners and Losers' article in the Economist. So, most of the oil producing countries have to sell the oil barrel at least at $\$ 100$ to balance their budgets.

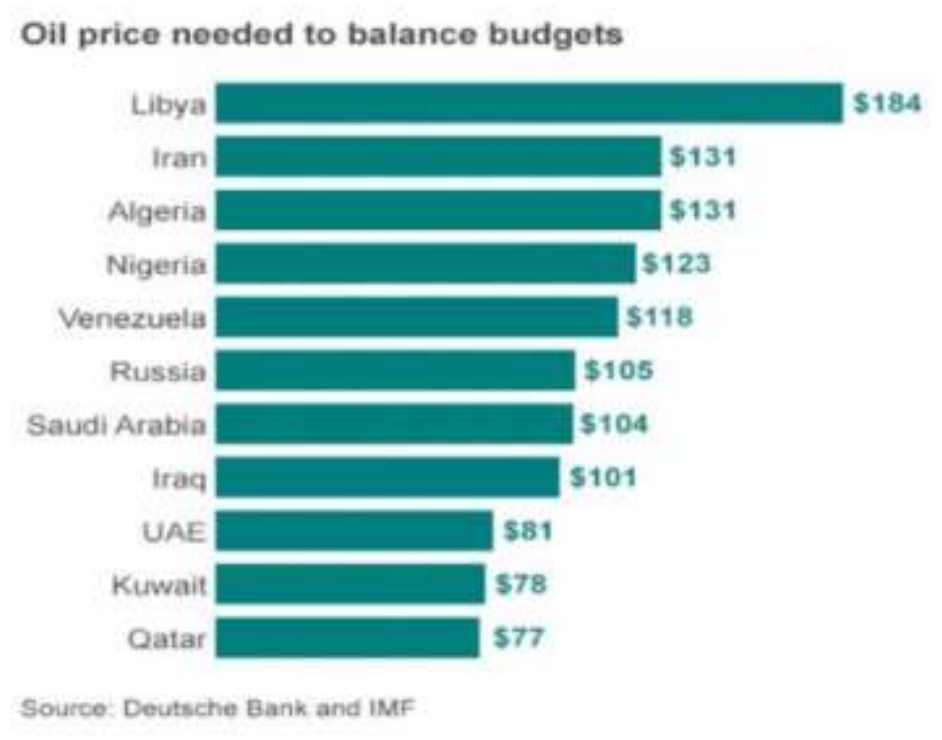

Figure 1. Oil Price Needed to Balance budget

The UAE, however, benefitted greatly from the price of oil during some years but experienced great fluctuations in its economic growth during the same time, evidenced by the fact that its GDP grew by $12.3 \%$ in 2000 but only by $3.2 \%$ in 2007 . Decline in the oil price has deteriorated economic performance of country. Large current account surplus has gone down almost to zero. The UAE also experienced a budget deficit in 2009 and 2010 of $17.7 \%$ to $3.1 \%$ of its GDP due to low oil prices and increased investment in areas of job creation and education aimed to foster more growth and human capital in the nation (The World Fact book: UAE, 2016). Further, in 2015, UAE eliminated its fuel subsidies to reduce national spending (Shahine, 2015). General government revenue to GDP ratio has decreased from 40\% in 2013 to 30\% in 2015 (and is expected to stay on this level in the next few years). GDP growth has also decreased, but still country is expected to grow at rate of $3 \%$ per year.

\subsection{Problem statement}

This research hence investigates the different connections between oil prices, resource management of oil demand and the impact economy of country. It tries to explore the long term effect of oil prices and demand on economic development of UAE country. The management supply-side of the oil market sector is significantly concerns with unrefined petroleum save and the difficulties required in making them accessible in the market sector. Therefore, the research concentrates on evaluating oil demand connection 
which can serve as a valuable apparatus for investigating long term activity in the oil industry. As mentioned in Energy Information Administration report, oil demand has been declining in the propelled districts chiefly because of efficiency of resource management - subsequently, it is critical to catch the effect of vitality efficiency when evaluating oil demand connections. In general, the research is finding the obstacle in resource management for economic growth with oils prices and demand in UAE.

Ftiti et al. (2016) the researcher studied the degree of interdependence between oil price shocks and economic growth for (United Arab Emirates, Kuwait, Saudi Arabia, and Venezuela) in OPEC during the period from 2000 to 2010. They used co-integration test, the researcher showed that oil price shock shortterm and medium-term during the period of fluctuations in financial turmoil and the global business cycle impact on economic growth in Organization of the Petroleum Exporting Countries. The effect of the medium-term effects is greater than that of the short-term effects.

\subsection{Objectives}

The specific research objectives conducted in this study are: (1) To investigate effects on budget during petroleum price fluctuation. Other objectives are: (1) To examine impact of fiscal policy of UAE on the budget of UAE; (2) To investigate effects of petroleum production on the budget of UAE; (3) To investigate effects of OPEC regulation on petroleum production.

\section{Methodology of research}

Quantitative methodology was used with the application of structured questionnaire.

According to the formula below by Yamane (1967) who provides a simplified formula to calculate sample sizes is used for sample size calculation. A 95\% confidence level and $P=0.5$ are assumed for the equation. This is sufficient and suitable for most of the researcher needs.

$$
n=\left(\frac{N}{1+N e^{2}}\right)
$$

Where: $\mathrm{N}=$ population size, $\mathrm{n}=$ sample size, $\mathrm{e}=$ error.

If the total population is 6540 , error is $5 \%$, after calculation, the sample size becomes, 150 people. This is the sample for this study. SPSS used for data analysis.

\section{Data analysis}

Table 1. Cronbach alpha coefficient

\begin{tabular}{|c|c|}
\hline Cronbach's Alpha & N of Items \\
\hline .720 & 3 \\
\hline
\end{tabular}

Here the value of Cronbach's Alpha is 0.720 which indicates the internal consistency of our data. If the value of Alpha is greater than 0.5 then the result is acceptable otherwise it is not acceptable. The calculated value of Alpha is greater than 0.720 so the internal consistency of data for evaluation of budget control due to fluctuation of petroleum price is acceptable.

\subsection{Assess the Trend of budget performance}

Table 2. How does your ministry evaluate its budget performance

\begin{tabular}{|l|l|c|c|c|c|}
\hline & & Frequency & Percent & $\begin{array}{c}\text { Valid } \\
\text { Percent }\end{array}$ & $\begin{array}{c}\text { Cumulative } \\
\text { Percent }\end{array}$ \\
\hline Valid & $\begin{array}{l}\text { do not calculate the variance between actual and budgeted } \\
\text { performance. }\end{array}$ & 41 & 27.3 & 27.3 & 27.3 \\
\cline { 2 - 6 } & $\begin{array}{l}\text { Do not calculate variance between but compare actual } \\
\text { performance and budgeted performance and attempt to } \\
\text { achieve budget target. }\end{array}$ & 50 & 33.3 & 33.3 & 60.7 \\
\cline { 2 - 6 } & $\begin{array}{l}\text { Regularly calculate variance in respect of various operational } \\
\text { aspects and take suitable remedial action. }\end{array}$ & 49 & 32.7 & 32.7 & 93.3 \\
\hline & None of above & 10 & 6.7 & 6.7 & 100.0 \\
\hline
\end{tabular}




\begin{tabular}{|c|c|c|c|c|c|}
\hline & & Frequency & Percent & $\begin{array}{l}\text { Valid } \\
\text { Percent }\end{array}$ & $\begin{array}{l}\text { Cumulative } \\
\text { Percent }\end{array}$ \\
\hline \multirow[t]{5}{*}{ Valid } & $\begin{array}{l}\text { do not calculate the variance between actual and budgeted } \\
\text { performance. }\end{array}$ & 41 & 27.3 & 27.3 & 27.3 \\
\hline & $\begin{array}{l}\text { Do not calculate variance between but compare actual } \\
\text { performance and budgeted performance and attempt to } \\
\text { achieve budget target. }\end{array}$ & 50 & 33.3 & 33.3 & 60.7 \\
\hline & $\begin{array}{l}\text { Regularly calculate variance in respect of various operational } \\
\text { aspects and take suitable remedial action. }\end{array}$ & 49 & 32.7 & 32.7 & 93.3 \\
\hline & None of above & 10 & 6.7 & 6.7 & 100.0 \\
\hline & Total & 150 & 100.0 & 100.0 & \\
\hline
\end{tabular}

Source: Field Data

A total of 150 questionnaires were distributed and all were filled and returned giving a response rate of $100 \% .41(27.3 \%)$ of the respondents believed that the ministry evaluated its budget performance by not calculating the variance between actual and budgeted performance. 55(33.3\%) of the respondents believed that the ministry evaluated its budget performance by not calculating variance between but compare actual performance and budgeted performance and attempt to achieve budget target and 49(32.7) of the respondents believed that the ministry evaluated its budget performance by regularly calculating variance in respect of various operational aspects and taking suitable remedial action. Only 10(6.7\%) of the respondents believed that other were some others processes.

Table 3. How are your ministry's current revenue compared to the previous years

\begin{tabular}{|c|c|c|c|c|c|}
\hline & & Frequency & Percent & Valid Percent & Cumulative Percent \\
\hline \multirow{3}{*}{ Valid } & increased & 51 & 34.0 & 34.0 & 34.0 \\
\cline { 2 - 6 } & decreased & 79 & 52.7 & 52.7 & 86.7 \\
\cline { 2 - 6 } & remained constant & 20 & 13.3 & 13.3 & 100.0 \\
\cline { 2 - 6 } & Total & 150 & 100.0 & 100.0 & \\
\hline
\end{tabular}

Source: Field Data

A total of 150 questionnaires were distributed and all were filled and returned giving a response rate of $100 \%$.According to the study finding that are presented in the above table, $79(52.7 \%)$ of the respondents revealed that the current ministry's revenue decreased compared to the previous years and $51(24 \%)$ of the respondents revealed that the current ministry's revenue increased as compared to the previous years due to the changes in the economic conditions. $20(13.3 \%)$ reported that the current ministry's revenue remain constant compared to the previous years.

Table 4. How are your organization current expenditures compared to the previous years

\begin{tabular}{|c|l|c|c|c|c|}
\hline \multirow{3}{*}{ Valid } & Frequency & Percent & Valid Percent & Cumulative Percent \\
\cline { 2 - 6 } & increased & 66 & 44.0 & 44.0 & 44.0 \\
\cline { 2 - 6 } & decreased & 69 & 46.0 & 46.0 & 90.0 \\
\cline { 2 - 6 } & remained constant & 15 & 10.0 & 10.0 & 100.0 \\
\cline { 2 - 6 } & \multicolumn{1}{|r}{ Total } & 150 & 100.0 & 100.0 & \\
\hline
\end{tabular}

Source: Field Data

A total of 150 questionnaires were distributed and all were filled and returned giving a response rate of $100 \%$. According to the study finding that are presented in the above table, 69 (46\%) of the respondents revealed that the current organization expenditures decreased compared to the previous years and $66(44 \%)$ of the respondents revealed that the current organization expenditures increased compared to the previous years. $20(13.3 \%)$ reported that the current organization expenditure remain constant compared to the previous years. 
Table 5. Are ministry's sales and expenditures according to the budgets/targets

\begin{tabular}{|c|l|c|c|c|c|}
\hline \multirow{3}{*}{ Valid } & & Frequency & Percent & Valid Percent & Cumulative Percent \\
\cline { 2 - 6 } & targets reached & 73 & 48.7 & 48.7 & 48.7 \\
\cline { 2 - 6 } & targets not reached & 42 & 28.0 & 28.0 & 76.7 \\
\cline { 2 - 6 } & others & 35 & 23.3 & 23.3 & 100.0 \\
\cline { 2 - 6 } \\
\cline { 2 - 6 }
\end{tabular}

Source: Field Data

A total of 150 questionnaires were distributed and all were filled and returned giving a response rate of $100 \%$. According to the study finding that are presented in the above table, $48.7 \%$ (73) of the respondents revealed that the ministry's sales and expenditures were reached to the target. 28\% (42) of the respondents revealed that the targets were not achieved. A total of 150 questionnaires were distributed and all were filled and returned giving a response rate of $100 \%$.

\subsection{Budget planning and budgetary control practices}

Table 6. The ministry has a long term and sort term budget plans

\begin{tabular}{|c|l|c|c|c|c|}
\hline & & Frequency & Percent & Valid Percent & Cumulative Percent \\
\hline \multirow{3}{*}{ Valid } & strongly agree & 30 & 20.0 & 20.0 & 20.0 \\
\cline { 2 - 6 } & agree & 105 & 70.0 & 70.0 & 90.0 \\
\cline { 2 - 6 } & neutral & 15 & 10.0 & 10.0 & 100.0 \\
\cline { 2 - 6 } & \multicolumn{1}{|c|}{ Total } & 150 & 100.0 & 100.0 & \\
\hline
\end{tabular}

Source: Field Data

A total of 150 questionnaires were distributed and all were filled and returned giving a response rate of $100 \%$.According to the table, $20 \%(30)$ of the respondents strongly agreed thatThe ministry has a long term and sort term budget plans, $70 \%$ (105) agreed with this statement and $10 \%(15)$ were neutral.

Table 7. The budgets have clear goals and objectives

\begin{tabular}{|c|l|c|c|c|c|}
\hline & & Frequency & Percent & Valid Percent & Cumulative Percent \\
\hline \multirow{3}{*}{ Valid } & strongly agree & 85 & 56.7 & 56.7 & 56.7 \\
\cline { 2 - 6 } & agree & 48 & 32.0 & 32.0 & 88.7 \\
\cline { 2 - 6 } & neutral & 17 & 11.3 & 11.3 & 100.0 \\
\cline { 2 - 6 } & Total & 150 & 100.0 & 100.0 & \\
\hline
\end{tabular}

Source: Field Data

A total of 150 questionnaires were distributed and all were filled and returned giving a response rate of $100 \%$. This section sought to analyses the budgeting process and to do so the respondents were asked a set of questions where they were to state the extent of their agreement to the statements with a scale of 1-3 where $1=$ strongly agree, $2=$ agree; $3=$ Neutral. According to the study finding that are presented in the above table, $85(56.7 \%)$ of the respondents strongly agreed that the budgets have clear goals and objectives, $32 \%$ (48) agreed with this statement and $11.3 \%$ were remain neutral.

Table 8. When budgeting, outcomes, goals and objectives are linked to programs and activities

\begin{tabular}{|c|c|c|c|c|c|}
\hline & & Frequency & Percent & Valid Percent & Cumulative Percent \\
\hline \multirow[t]{5}{*}{ Valid } & strongly agree & 44 & 29.3 & 29.3 & 29.3 \\
\hline & agree & 91 & 60.7 & 60.7 & 90.0 \\
\hline & neutral & 13 & 8.7 & 8.7 & 98.7 \\
\hline & disagree & 2 & 1.3 & 1.3 & 100.0 \\
\hline & Total & 150 & 100.0 & 100.0 & \\
\hline
\end{tabular}

Source: Field Data 
A total of 150 questionnaires were distributed and all were filled and returned giving a response rate of $100 \%$.According to the table, $29.3 \%$ of the respondents strongly agreed that when budgeting, outcomes, goals and objectives are linked to programs and activities., $60 \%$ agreed with this statement, $8.7 \%$ were remain neutral and $1.3 \%$ disagreed.

Table 9. The ministry put priorities for the coming annual budget conference and committees

\begin{tabular}{|l|l|c|c|c|c|}
\hline & & Frequency & Percent & Valid Percent & Cumulative Percent \\
\hline \multirow{3}{*}{ Valid } & strongly agree & 75 & 50.0 & 50.0 & 50.0 \\
\cline { 2 - 6 } & agree & 60 & 40.0 & 40.0 & 90.0 \\
\cline { 2 - 6 } & neutral & 15 & 10.0 & 10.0 & 100.0 \\
\cline { 2 - 6 } & Total & 150 & 100.0 & 100.0 & \\
\hline
\end{tabular}

A total of 150 questionnaires were distributed and all were filled and returned giving a response rate of $100 \%$. According to the table above, $75(50 \%)$ of the respondents strongly agreed that the ministry put priorities for the coming annual budget conference and committees.60 $(40 \%)$ of the respondents agreed with this statement and 15 (10\%) were neutral.

Table 10. Ministry's departments prepare budget plans prior to the budget year

\begin{tabular}{|l|l|c|c|c|c|}
\hline \multirow{3}{*}{ Valid } & & Frequency & Percent & Valid Percent & Cumulative Percent \\
\cline { 2 - 6 } & strongly agree & 58 & 38.7 & 38.7 & 38.7 \\
\cline { 2 - 6 } & agree & 83 & 55.3 & 55.3 & 94.0 \\
\cline { 2 - 6 } & neutral & 7 & 4.7 & 4.7 & 98.7 \\
\cline { 2 - 6 } & strongly disagree & 2 & 1.3 & 1.3 & 100.0 \\
\cline { 2 - 6 } & Total & 150 & 100.0 & 100.0 & \\
\hline
\end{tabular}

Source: Field Data

A total of 150 questionnaires were distributed and all were filled and returned giving a response rate of $100 \%$. According to the table above, $58(38.7 \%)$ of the respondents strongly agreed that ministry's departments prepare budget plans prior to the budget year, 83 (55.3\%) of the respondents agreed with this statement, $7(4.7 \%)$ were neutral and $2(1.3 \%)$ strongly disagreed.

\subsection{The contribution of budget in the financial performance of the Ministry of Interior}

Table 11. For the following key performance indicators of the ministry the past budget periods revenue(sales) growth

\begin{tabular}{|l|l|c|c|c|c|}
\hline \multirow{3}{*}{ Valid } & Frequency & Percent & Valid Percent & Cumulative Percent \\
\cline { 2 - 6 } & much worse off & 12 & 8.0 & 8.0 & 8.0 \\
\cline { 2 - 6 } & somehow worse of & 4 & 2.7 & 2.7 & 10.7 \\
\cline { 2 - 6 } & about the same & 13 & 8.7 & 8.7 & 19.3 \\
\cline { 2 - 6 } & somehow better off & 114 & 76.0 & 76.0 & 95.3 \\
\cline { 2 - 6 } & much better off & 7 & 4.7 & 4.7 & 100.0 \\
\cline { 2 - 6 } & Total & 150 & 100.0 & 100.0 & \\
\hline
\end{tabular}

Source: Field Data

A total of 150 questionnaires were distributed and all were filled and returned giving a response rate of $100 \%$. According to the table above, $8 \%$ (12) of the respondents revealed thatfor the following key performance indicators of the ministry the past budget periods -revenue (sales) growth was much worse off, $2.7 \%$ (4) of the respondents revealed as somehow worse, $8.7 \%$ (13) said as about the same, $76 \%$ (114) considered as somehow better off and $4.7 \%$ (7) revealed as much better off. 
Table 12. For the following key performance indicators of the ministry the past budget periods-return on investment (ROI)

\begin{tabular}{|l|l|c|c|c|c|}
\hline & & Frequency & Percent & Valid Percent & Cumulative Percent \\
\hline \multirow{4}{*}{ Valid } & much worse off & 10 & 6.7 & 6.7 & 6.7 \\
\cline { 2 - 6 } & somehow worse off & 3 & 2.0 & 2.0 & 8.7 \\
\cline { 2 - 6 } & about the same & 27 & 18.0 & 18.0 & 26.7 \\
\cline { 2 - 6 } & somehow better off & 39 & 26.0 & 26.0 & 52.7 \\
\cline { 2 - 6 } & much better off & 71 & 47.3 & 47.3 & 100.0 \\
\cline { 2 - 6 } & Total & 150 & 100.0 & 100.0 & \\
\hline
\end{tabular}

Source: Field Data

A total of 150 questionnaires were distributed and all were filled and returned giving a response rate of $100 \%$. According to the table above, $6.7 \%(10)$ of the respondents revealed that for the following key performance indicators of the ministry the past budget periods -return on investment (ROI) was much worse off, $2 \%$ (3) of the respondents revealed as somehow worse off, $18 \%$ (27) said as about the same, $26 \%$ (39) considered as somehow better off and $47.3 \%$ (71) revealed as much better off.

Table 13. Budgeted performance as $100 \%$. what percentage value would you assign to the following key financial performance indicators based on your ministry's actual performance against the budgeted performance in the last budget periods-revenue(sales) growth

\begin{tabular}{|l|l|c|c|c|c|}
\hline & & Frequency & Percent & Valid Percent & Cumulative Percent \\
\hline \multirow{4}{*}{ Valid } & more than $100 \%$ & 75 & 50.0 & 50.0 & 50.0 \\
\cline { 2 - 6 } & $75 \%$ to $100 \%$ & 50 & 33.3 & 33.3 & 83.3 \\
\cline { 2 - 6 } & $50 \%$ to $75 \%$ & 23 & 15.3 & 15.3 & 98.7 \\
\cline { 2 - 6 } & $25 \%$ to $50 \%$ & 2 & 1.3 & 1.3 & 100.0 \\
\cline { 2 - 6 } & Total & 150 & 100.0 & 100.0 & \\
\hline
\end{tabular}

Source: Field Data

A total of 150 questionnaires were distributed and all were filled and returned giving a response rate of $100 \%$. According to the table above, $50 \%$ (75) of the respondents revealed that the percentage value assigned to the following key financial performance indicators based on ministry's actual performance against the budgeted performance in the last budget periods-revenue (sales) growth was more than $100 \%$, $33.3 \%(50)$ of the respondents revealed as $75 \%$ to $100 \%, 15.3 \%$ (23) expressed as $50 \%$ to $75 \%$ and $1.3 \%$ (2) considered as 25 to $50 \%$.

Table 14. Consider the budgeted performance as $100 \%$. what percentage value would you assign to the following key financial performance indicators based on your ministry's actual performance against the budgeted performance in the last budget periods-return on investment(ROI):

\begin{tabular}{|l|l|c|c|c|c|}
\hline & & Frequency & Percent & Valid Percent & Cumulative Percent \\
\hline \multirow{3}{*}{ Valid } & more than $100 \%$ & 79 & 52.7 & 52.7 & 52.7 \\
\cline { 2 - 6 } & $75 \%$ to $100 \%$ & 45 & 30.0 & 30.0 & 82.7 \\
\cline { 2 - 6 } & $50 \%$ to $75 \%$ & 20 & 13.3 & 13.3 & 96.0 \\
\cline { 2 - 6 } & $25 \%$ to $50 \%$ & 5 & 3.3 & 3.3 & .7 \\
\cline { 2 - 6 } & $0 \%$ to $25 \%$ & 1 & .7 & 100.0 & 100.0 \\
\cline { 2 - 6 } \\
\cline { 2 - 6 }
\end{tabular}

Source: Field Data

A total of 150 questionnaires were distributed and all were filled and returned giving a response rate of $100 \%$. According to the table, $52.7 \%$ (79) of the respondents revealed that the percentage value I assigned to the following key financial performance indicators based on ministry's actual performance 
against the budgeted performance in the last budget periods-return on investment (ROI) was more than $100 \%, 30 \%$ (45) of the respondents revealed as $75 \%$ to $100 \%, 13.3 \%$ (20) expressed as $50 \%$ to $75 \%, 3.3 \%$ (5) considered as 25 to $50 \%$ and . $7 \%$ (1) said as $0 \%$ to $25 \%$.

Table 15. Rate how well the ministry is performing in terms its internal operation based on your ministry's actual performance against budgeted performance in the last budget periods-units produced/generated

\begin{tabular}{|c|l|c|c|c|c|}
\hline \multirow{3}{*}{ Valid } & Frequency & Percent & Valid Percent & Cumulative Percent \\
\cline { 2 - 6 } & much worse off & 11 & 7.3 & 7.3 & 7.3 \\
\cline { 2 - 6 } & somehow worse off & 3 & 2.0 & 2.0 & 9.3 \\
\cline { 2 - 6 } & about the same & 16 & 10.7 & 10.7 & 20.0 \\
\cline { 2 - 6 } & somehow better off & 104 & 69.3 & 69.3 & 10.3 \\
\cline { 2 - 6 } & much better off & 16 & 10.7 & 100.0 & \\
\cline { 2 - 6 } & Total & 150 & 100.0 & & \\
\hline
\end{tabular}

Source: Field Data

A total of 150 questionnaires were distributed and all were filled and returned giving a response rate of $100 \%$. According to the table above, $7.3 \%$ (11) of the respondents revealed that rate how well the ministry is performing in terms its internal operation based on ministry's actual performance against budgeted performance in the last budget periods-units produced/generated was much worse off, $2 \%$ (3) of the respondents revealed as somehow worse off, $10.7 \%$ (16) said as about the same, $69.3 \%$ (104) considered as somehow better off and $10.7 \%(16)$ revealed as much better off.

Table 16. Rate how well the ministry is performing in terms its internal operation based on your ministry's actual performance against budgeted performance in the last budget periods-cost effectiveness

\begin{tabular}{|l|l|c|c|c|c|}
\hline & & Frequency & Percent & Valid Percent & Cumulative Percent \\
\hline \multirow{3}{*}{ Valid } & much worse off & 10 & 6.7 & 6.7 & 6.7 \\
\cline { 2 - 6 } & somehow worse off & 4 & 2.7 & 2.7 & 9.3 \\
\cline { 2 - 6 } & about the same & 5 & 3.3 & 3.3 & 12.7 \\
\cline { 2 - 6 } & somehow better off & 40 & 26.7 & 26.7 & 39.3 \\
\cline { 2 - 6 } & much better off & 91 & 60.7 & 60.7 & 100.0 \\
\cline { 2 - 6 } \\
\cline { 2 - 6 } & Total & 150 & 100.0 & 100.0 & \\
\hline
\end{tabular}

Source: Field Data

A total of 150 questionnaires were distributed and all were filled and returned giving a response rate of $100 \%$. According to the table, $6.7 \%(10)$ of the respondents revealed thatrate how well the ministry is performing in terms its internal operation based on your ministry's actual performance against budgeted performance in the last budget periods-cost effectiveness was much worse off, $2.7 \%$ (4) of the respondents revealed as somehow worse off, $3.3 \%$ (5) said as about the same, $26.7 \%$ (40) considered as somehow better off and $60.7 \%$ (91) revealed as much better off.

Table 17. Do u think budgets contribute positively to the financial performance of the ministry

\begin{tabular}{|c|l|c|c|c|c|}
\hline & & Frequency & Percent & Valid Percent & Cumulative Percent \\
\hline \multirow{3}{*}{ Valid } & contribute to performance & 41 & 27.3 & 27.3 & 27.3 \\
\cline { 2 - 6 } & doesn't contribute to performance & 73 & 48.7 & 48.7 & 76.0 \\
\cline { 2 - 6 } & not sure & 36 & 24.0 & 24.0 & 100.0 \\
\cline { 2 - 6 } & Total & 150 & 100.0 & 100.0 & \\
\hline
\end{tabular}

Source: Field Data

A total of 150 questionnaires were distributed and all were filled and returned giving a response rate of $100 \%$. According to the table, $27.3 \%$ (41) of the respondents' revealed thatbudgets contribute positively 
to the financial performance of the ministry, $48.7 \%$ (73) revealed that budgets don't contribute positively to the financial performance and $24 \%(36)$ were not sure.

The findings revealed that majority of the respondents to a large extent don't agree that budgets contribute positively to the financial performance of the ministry. It was also noted, the respondents to a large extent agreed that budgets contribute positively to the financial performance of the ministry.

\subsection{Correlations Test}

Table 18. Correlations Test

\begin{tabular}{|c|c|c|c|c|c|}
\hline & & Budgetary Control & Fiscal Policy & OPEC Regulations & Petroleum Production \\
\hline \multirow[t]{3}{*}{ Budgetary Control } & Pearson Correlation & 1 & $.314^{* *}$ & $.436^{* *}$ & $.546^{* *}$ \\
\hline & Sig. (2-tailed) & & .000 & .000 & .000 \\
\hline & $N$ & 150 & 150 & 150 & 150 \\
\hline \multirow[t]{3}{*}{ Fiscal Policy } & Pearson Correlation & $.314^{* *}$ & 1 & $.595^{* *}$ & $.685^{* *}$ \\
\hline & Sig. (2-tailed) & .000 & & .000 & .000 \\
\hline & $\mathrm{N}$ & 150 & 150 & 150 & 150 \\
\hline \multirow[t]{3}{*}{ OPEC Regulations } & Pearson Correlation & $.436^{* *}$ & $.595^{* *}$ & 1 & $.545^{* *}$ \\
\hline & Sig. (2-tailed) & .000 & & & .000 \\
\hline & $N$ & 150 & 150 & 150 & 150 \\
\hline \multirow[t]{3}{*}{ Petroleum Production } & Pearson Correlation & $.546^{* *}$ & $.685^{* *}$ & $.545^{* *}$ & 1 \\
\hline & Sig. (2-tailed) & .000 & .000 & .000 & \\
\hline & $\mathrm{N}$ & 150 & 150 & 150 & 150 \\
\hline
\end{tabular}

From above table we can see the value of correlation coefficient $r$. we know the values of $r$ lies between -1 to 1 . If the value is close to 1 then there exists a strong relationship between the variables. And also, if the value of $r$ close to zero then there exist weak relation between the variables. If the value of $r$ is negative then there exists native relation between the variables.

From above table:

- The relationship between Budgetary Control and Fiscal Policy is approximately good because the value of the coefficient is 0.314 .

- The relationship between Budgetary Control and Petroleum Production is approximately good because the value of the coefficient is 0.546 .

- The relationship between Budgetary Control and OPEC Regulations is approximately good because the value of the coefficient is 0.436 .

- The relationship between Fiscal Policy and Petroleum Production is approximately good because the value of the coefficient is 0.685 .

- The relationship between Budgetary Control and Petroleum Production is approximately good because the value of the coefficient is 0.546 .

- The relationship between Budgetary Control and OPEC Regulations is approximately good because the value of the coefficient is 0.436 .

- The relationship between Fiscal Policy and Petroleum Production is approximately good because the value of the coefficient is 0.685 .

Well, after examining the evaluation of budgetary control due to fluctuation of petroleum price: a study on the ministry of interior in the UAE. The first objective of the study, it is seen that there is a positive effect of price of petroleum fluctuation to ministry budget allocation. There is not cost elimination but there is an in built process now for cost minimization. Secondly, impact of the fiscal policy has a direct impact on the budget. As fiscal policy consist of taxation and government expenditure, so the government now should look for alternate indirect tax to increase the inflow for the government as a measure to reduce the negative burden on petroleum price fluctuations. Thirdly, United Arab Emirates still complying with the 
OPEC policy for the production of barrels per day, while some countries are producing more than the daily production level. This is causing further decline in oil prices globally.

\section{Conclusions}

Oil prices have been on a roller-coaster ride over the last few years. This research examined the evaluation of budgetary control due to fluctuation of petroleum price. The study was conducted in the ministry of interior, United Arab Emirates to undermine the evaluation of the budgetary control due to the fluctuation of petroleum price. Since the main source of revenue for the Government is petroleum so, the public sector budgets heavily depends on the global petroleum price and the fluctuation of it has a direct impact on the public sector operation. Budgetary control helps planning, coordination between departments, decision-making, monitoring of operating results and motivation of personnel to achieve organizational objectives. Moreover, it entails the establishment of goals by the management of an organization and designing a process which serves as a framework within which an organization effectively articulates overall planned activities. Ministry of interior being the key public sector is also within the strategic concern of the government revenue and its implication on its budgetary affairs. It therefore recommended that since budgeting and budgetary control contributes to management efficiency and high productivity of an organization, all relevant stakeholders must be involved in the budget process, from preparation to implementation, in other to guarantee overall goal attainment.

\section{Recommendations}

The following recommendations can be listed from all the analysis for an evaluation of budgetary control due to fluctuation of petroleum price: a study on the ministry of interior in the UAE.

- Firstly, it is very common phenomenon for the oil price to fluctuate, hence alternative source of income to be generated so that dependency only from oil price for budget for the ministry of interior can be minimized.

- Secondly, to introduce new elements in the fiscal policy of the country as alternate source of government revenue likes looking into public revenue and expenses. Concentration on invisible exports to be considered. Like tourism, education, health care etc.

- Thirdly, reform of OPEC policy's on petroleum production per day quota need to be relooked due to persistent fall of the oil price as to adjust the supply and demand.

- Fourthly, introduction of more training program as to minimize the workplace wastage by implementation of lean management and Six Sigma as well. Thus to an extent overheads may be reduced and ministry requiring less annual budget.

- Fifthly, a cell for Cost effectiveness due to budget variance need to be implemented so that the department can scrutiny each of the items of the ministry expenses to ensure as per proper budget allocation the money is spend.

- Sixthly, e budget variance newsletter, smart phone technology to be introduced to increase awareness for reduction in wastages and optimal utilization for resources.

\section{Limitation of the research}

The following limitation was observed by the researcher:

- Firstly, the collection of data had an issue as many employees were not so much aware of the critical issues on fiscal policy matters and its implication on budgets.

- Secondly, the time framework.

- Finally, most of the data are very classified and used here very cautiously. 


\section{References}

1. Al Dulaimi, H. A. M. (2014). The Collapse of Crude Oil Prices: Cyclical Evolution or Market Manipulation?. Economic Insights - Trends and Challenges Vol. III (LXVI) No. 4, 89-96.

2. Baumeister, C., \& Kilian, L. (2015). Forecasting the Real Price of Oil in a Changing World: A Forecast Combination Approach, Journal of Business \& Economic Statistics, 33:3, 338-351, DOI: 10.1080/07350015.2014.949342

3. Demirbas, A., Al-Sasi, B. O., \& Nizami, A. S. (2017). Recent volatility in the price of crude oil, Energy Sources, Part B: Economics, Planning, and Policy, 12:5, 408-414.

4. Energy Information Administration (2014). Annual Energy Outlook 2014 with projections to 2040.

5. Ftiti, Z., Guesmi, K., Teulon, F., \& Chouachi, S. (2016). Relationship between crude oil prices and economic growth in selected OPEC countries. Journal of Applied Business Research, 32(1), 11.

6. O'Sullivan, A., Sheffrin, S. M., \& Perez, S. J. (2007). Survey of economics. Prentice Hall.

7. Shahine, A. (2015). Oil Rout Means Fewer Freebies in GCC as Subsidies Are Cut. Retrieved from http://www.bloomberg.com/articles/2015-01-13/ (July 20, 2016). 